\title{
Front Matter: Volume 6556
}

, "Front Matter: Volume 6556," Proc. SPIE 6556, Micro (MEMS) and Nanotechnologies for Defense and Security, 655601 (23 May 2007); doi: $10.1117 / 12.739130$

SPIE Event: Defense and Security Symposium, 2007, Orlando, Florida, United SPIE. States 


\title{
PROCEEDINGS OF SPIE
}

\section{Micro (MEMS) and Nanotechnologies for Defense and Security}

\author{
Thomas George \\ Zhongyang Cheng
}

Editors

10-12 April 2007

Orlando, Florida, USA

Sponsored and Published by

SPIE-The International Society for Optical Engineering

Volume 6556

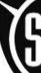


The papers included in this volume were part of the technical conference cited on the cover and title page. Papers were selected and subject to review by the editors and conference program committee. Some conference presentations may not be available for publication. The papers published in these proceedings reflect the work and thoughts of the authors and are published herein as submitted. The publisher is not responsible for the validity of the information or for any outcomes resulting from reliance thereon.

Please use the following format to cite material from this book:

Author(s), "Title of Paper," in Micro (MEMS) and Nanotechnologies for Defense and Security, edited by Thomas George, Zhongyang Cheng, Proceedings of SPIE Vol. 6556 (SPIE, Bellingham, WA, 2007) Article CID Number.

ISSN 0277-786X

ISBN 9780819466785

Published by

SPIE-The International Society for Optical Engineering

P.O. Box 10, Bellingham, Washington 98227-0010 USA

Telephone 1 360/676-3290 (Pacific Time) · Fax 1 360/647-1445

http://www.spie.org

Copyright (C) 2007, The Society of Photo-Optical Instrumentation Engineers

Copying of material in this book for internal or personal use, or for the internal or personal use of specific clients, beyond the fair use provisions granted by the U.S. Copyright Law is authorized by SPIE subject to payment of copying fees. The Transactional Reporting Service base fee for this volume is $\$ 18.00$ per article (or portion thereof), which should be paid directly to the Copyright Clearance Center (CCC), 222 Rosewood Drive, Danvers, MA 01923. Payment may also be made electronically through CCC Online at http://www.copyright.com. Other copying for republication, resale, advertising or promotion, or any form of systematic or multiple reproduction of any material in this book is prohibited except with permission in writing from the publisher. The CCC fee code is 0277 $786 \times / 07 / \$ 18.00$

Printed in the United States of America. 


\title{
Contents
}

$\begin{array}{ll}\text { ix } & \text { Conference Committee } \\ \text { xi Introduction }\end{array}$

\author{
SESSION 1 COMPLEX MEMS AND NANODEVICES \\ 655602 Complex MEMS device: microshutter array system for space applications (Invited Paper) \\ [6556-01] \\ M. J. Li, T. Adachi, C. Allen, S. Babu, S. Bajikar, M. Beamesderfer, R. Bradley, K. Denis, \\ N. Costen, A. Ewin, D. Franz, L. Hess, R. Hu, K. Jackson, M. Jhabvala, D. Kelly, T. King, \\ G. Kletetschka, A. Kutyrev, B. Lynch, T. Miller, H. Moseley, V. Mikula, B. Mott, L. Oh, J. Pontius, \\ D. Rapchun, C. Ray, K. Ray, E. Schulte, S. Schwinger, P. Shu, R. Silverberg, W. Smith, \\ S. Snodgrass, D. Sohl, L. Sparr, R. Steptoe-Jackson, V. Valeriano, L. Wang, Y. Zheng, \\ C. Zincke, NASA Goddard Space Flight Ctr. (USA)
}

655604 Micropolarizer arrays in the MWIR for snapshot polarimetric imaging [6556-03]

S. A. Kemme, A. A. Cruz-Cabrera, P. Nandy, R. R. Boye, J. R. Wendt, Sandia National Labs.

(USA); T. R. Carter, S. Samora, L\&M Technologies, Inc. (USA)

655608 Deflection of silicon dioxide microbridge under distributed load [6556-57]

H. Li, A. Chakraborty, X. Liu, H. Wang, C. Luo, Louisiana Tech Univ. (USA)

\section{SESSION 2 MEMS ADAPTIVE OPTICS}

65560A Piezoelectric microactuator technologies for wavefront correction in space (Invited Paper) [6556-07]

E.-H. Yang, Stevens Institute of Technology (USA); Y. Hishinuma, Fuji Film Corp. (Japan);

R. Toda, K. Shcheglov, Jet Propulsion Lab. (USA)

Pagination: Proceedings of SPIE follow an e-First publication model, with papers published first online and then in print and on CD-ROM. Papers are published as they are submitted and meet publication criteria. A unique, consistent, permanent citation identifier (CID) number is assigned to each article at the time of the first publication. Utilization of CIDs allows articles to be fully citable as soon they are published online, and connects the same identifier to all online, print, and electronic versions of the publication.

SPIE uses a six-digit CID article numbering system in which:

- The first four digits correspond to the SPIE volume number.

- The last two digits indicate publication order within the volume using a Base 36 numbering system employing both numerals and letters. These two-number sets start with 00, 01, 02, 03, 04, 05, 06, 07, 08, 09, 0A, OB ... 0Z, followed by 10-1Z, 20-2Z, etc.

The CID number appears on each page of the manuscript. The complete citation is used on the first page, and an abbreviated version on subsequent pages. 
65560B MEMS deformable mirror optical limiter for dynamic range compression deconvolution [6556-08]

J. Khoury, C. L. Woods, Air Force Research Lab. (USA); B. Haji-saeed, Univ. of Massachusetts, Lowell (USA) and Solid State Scientific Corp. (USA); S. K. Sengupta, W. D. Goodhue, Univ. of Massachusetts, Lowell (USA); J. Kierstead, Solid State Scientific Corp. (USA)

65560C Optically addressed spring-patterned membrane mirror MEMS with megahertz response [6556-09]

B. Haji-saeed, Univ. of Massachusetts, Lowell (USA) and Solid State Scientific Corp. (USA);

G. Griffith, S. K. Sengupta, W. D. Goodhue, Univ. of Massachusetts, Lowell (USA); J. Khoury,

C. L. Woods, Air Force Research Lab. (USA); J. Kierstead, Solid State Scientific Corp. (USA)

\section{SESSION 3 PHOTONIC SENSORS I}

65560E Lab-on-a-chip bio/chemical sensing system based on the liquid core optical ring resonator (Invited Paper) [6556-11]

I. M. White, J. D. Suter, H. Zhu, H. Oveys, L. Brewington, J. Gohring, X. Fan, Univ. of Missouri, Columbia (USA)

65560F Novel chemical and biological fiber optic sensor [6556-12]

B. Scott, C. Ma, G. Pickrell, K. Cooper, A. Wang, T. Ooi, Virginia Tech (USA)

65560G Evanescent optical fluorescence excitation: the role of photonic mode density [6556-13] B. Menges, Max-Planck-Institute for Polymer Research (Germany); A. Sato, Max-PlanckInstitute for Polymer Research (Germany) and Tokyo Institute of Technology (Japan); W. Knoll, Max-Planck-Institute for Polymer Research (Germany)

$65560 \mathrm{H}$ High-speed nano-optical photodetector for free space communication [6556-14] R. M. Kurtz, K. A. Alim, R. D. Pradhan, V. Esterkin, G. D. Savant, Physical Optics Corp. (USA); R. Venkatasubramanian, M. L. Lee, RTI International (USA); S. Ghosh, I. Calizo,

A. A. Balandin, Univ. of California, Riverside (USA)

65560 Integrated optical microring for high-resolution refractive index and pressure sensing applications [6556-15]

S. Ja, ICX Nomadics (USA)

65560J Optical micro- and nanofibers for sensing applications [6556-16]

M. Sumetsky, OFS Labs. (USA)

\section{SESSION 4 PHOTONIC SENSORS II}

$65560 \mathrm{M}$ Microfluidic device detection of waterborne pathogens through static light scattering of latex immunoagglutination using proximity optical fibers [6556-19]

J.-Y. Yoon, J.-H. Han, B. Heinze, L. J. Lucas, The Univ. of Arizona (USA)

65560N Small form factor microsensor system using optical MEMS for passive optical digital communication (PODC) [6556-20]

W. Wang, S. Samson, R. Agarwal, J. Bumgarner, R. Hazen, S. Kedia, G. Gonzalez,

L. Langebrake, C. Munoz, E. Kaltenbacher, Univ. of South Florida (USA) 
$65560 \mathrm{Q}$ Tunable ferroelectric photonic crystals based on $\mathrm{Ba}_{0.7} \mathrm{Sr}_{0.3} \mathrm{TiO}_{3} / \mathrm{MgO}_{\text {multilayer thin films }}$ [6556-54]

D. Y. Wang, K. L. Jim, C. W. Leung, H. L. W. Chan, C. L. Choy, The Hong Kong Polytechnic Univ. (Hong Kong China)

65560R Theoretical study of ferroelectric barium-strontium-titanate-based one-dimensional tunable photonic crystals [6556-55]

K. L. Jim, D. Y. Wang, C. W. Leung, C. L. Choy, H. L. W. Chan, The Hong Kong Polytechnic Univ. (Hong Kong China)

\section{SESSION 5 DIP PEN/NANOLITHOGRAPHY I}

65560 Nanolithography of metal catalysts by Dip Pen Nanolithography (DPN) (Invited Paper) [6556-22]

D. Huitink, D. Banerjee, Texas A\&M Univ. (USA); S. K. Sinha, Univ. of New Haven (USA)

65560T Dip Pen Nanolithography: a maturing technology for high-throughput flexible nanopatterning [6556-23]

J. R. Haaheim, E. R. Tevaarwerk, J. Fragala, R. Shile, Nanolnk, Inc. (USA)

65560V Method of matrix alignment for nanostructure lithography [6556-25]

A. Sokolnikov, Visual Solutions and Applications (USA)

\section{SESSION 6 DIP PEN/NANOLITHOGRAPHY II}

65560Y Investigation of the conducting polymer microsensors generated using an intermediatelayer lithography method [6556-28]

A. Chakraborty, G. Parthasarathi, C. Luo, Louisiana Tech Univ. (USA)

$65560 Z$ Generation of conducting polymer-based heterojunctions, diodes, and capacitors using an intermediate-layer lithography method [6556-29]

X. Liu, A. Chakraborty, G. Parthasarathi, C. Luo, Louisiana Tech Univ. (USA)

\section{SESSION 7 MEMS/NANOSYSTEMS/ALGORITHMS}

655611 Tier-scalable reconnaissance: the challenge of sensor optimization, sensor deployment, sensor fusion, and sensor interoperability (Invited Paper) [6556-31]

W. Fink, California Institute of Technology (USA); T. George, ViaLogy LLC (USA); M. A. Tarbell, California Institute of Technology (USA)

655613 Miniaturized self-adaptive tuning of MEMS gyroscope for space [6556-33]

D. Keymeulen, M. I. Ferguson, L. Breuer, C. Peay, B. Oks, Jet Propulsion Lab. (USA);

Y. Cheng, D. Kim, Univ of California, Los Angeles (USA); E. MacDonald, D. Foor, R. Terrile,

N. Arenki, K. Yee, Univ. of Texas at El Paso (USA)

655614 Advanced signal processing for enabling next generation MEMS/NEMS sensors [6556-34]

T. George, S. Ben-Menahem, S. Gulati, E. Wang, J. K. Breaux, B. Bromley, ViaLogy LLC (USA)

655615 Reliability shortcomings for micronanotechnology-based systems (Invited Paper) [6556-35]

E. J. Garcia, M. A. Polosky, Sandia National Labs. (USA) 
655616 GaN-based microchemical sensor nodes for early warning of chemical agents (Invited Paper) [6556-36]

K.-A. Son, B. Yang, Jet Propulsion Lab. (USA); N. Prokopuk, Naval Air Warfare Ctr. (USA); J. S. Moon, HRL Labs., LLC (USA); A. Liao, M. Gallegos, Jet Propulsion Lab. (USA); J. Yang, M. A. Khan, Univ. of South Carolina (USA)

655617 Highly sensitive chemical sensors by functional integration of nanoporous zeolites with photonic devices [6556-37]

T. Wei, J. Montoya, H. Xiao, Univ. of Missouri, Rolla (USA); J. Zhang, H. Dong, Univ. of Cincinnati (USA)

655618 Performance of a carbon nanotube field emission electron gun [6556-38]

S. A. Getty, T. T. King, R. A. Bis, H. H. Jones, F. Herrero, B. A. Lynch, P. Roman, P. Mahaffy, NASA Goddard Space Flight Ctr. (USA)

655619 Detection of Bacillus anthracis spores in water using biosensors based on magnetostrictive microcantilever coated with phage [6556-39]

L. Fu, S. Li, K. Zhang, Z.-Y. Cheng, J.M. Barbaree, Auburn Univ. (USA)

65561 A Micro-initiators as the fundamental building blocks of micro-energetic systems (Invited Paper) [6556-40]

A. Desai, Tanner Research, Inc. (USA); B. Fuchs, U.S. Army Armament Research,

Development and Engineering Ctr. (USA)

$65561 \mathrm{~B}$ Computational survey of representative energetic materials as propellants for microthruster applications [6556-41]

B. Fuchs, U.S. Army Armament Research, Development and Engineering Ctr. (USA);

D. Stec III, SAIC (USA)

\section{SESSION 9 ADVANCED MEMS DEVICES II}

65561D Optical micro-resonator chemical sensor [6556-43]

A. Pyayt, X. Zhang, J. Luo, A. Jen, L. Dalton, A. Chen, Univ. of Washington (USA)

655611 Flexural plate wave devices for biosensor platform [6556-59]

S. H. Yoon, J.-H. Park, D. Shen, D.-J. Kim, Auburn Univ. (USA)

$65561 \mathrm{~J}$ Piezoelectric micromachined ultrasonic transducers with rectangular diaphragms for binary frequency applications [6556-60]

C. Chao, T.-Y. Lam, K.-W. Kwok, H. L. Chan, Hong Kong Polytechnic Univ. (Hong Kong China)

\section{SESSION 10 NANOWIRE DEVICES}

65561L Growth and characterization of ZnO nanowires for various sensor applications [6556-48] A. K. Sood, Magnolia Optical Technologies, Inc. (USA); Y. R. Puri, Magnolia Optical Technologies, Inc. (USA) and Univ. of Massachusetts, Lowell (USA); P. Gao, W. Mai, C. Lao, Z. L. Wang, Georgia Institute of Technology (USA); D. L. Polla, DARPA/MTO (USA);

M. B. Soprano, DARPA, U.S. Army, AMSRD (USA) 
$65561 \mathrm{~N}$ Review of an intermediate-layer lithography approach (Invited Paper) [6556-50]

C. LUo, Louisiana Tech Univ. (USA)

65561P Generation of silicon nanowires using a new thinning and trimming method [6556-56] H. Wang, A. Chakraborty, X. Liu, H. Li, C. Luo, Louisiana Tech Univ. (USA)

Author Index 
Downloaded From: https://www.spiedigitallibrary.org/conference-proceedings-of-spie on 26 Apr 2023

Terms of Use: https://www.spiedigitallibrary.org/terms-of-use 


\title{
Conference Committee
}

\author{
Symposium Chair
}

John C. Carrano, Luminex Corporation (USA)

Symposium Cochair

Larry B. Stotts, Defense Advanced Research Projects Agency (USA)

Program Track Chairs

Peter Tchoryk, Jr., Michigan Aerospace Corporation (USA)

Roger Hall, Advanced Research Projects Agency (USA)

Conference Chairs

Thomas George, ViaLogy Corporation (USA)

Zhongyang Cheng, Auburn University (USA)

Program Committee

Debjyoti Banerjee, Texas A\&M University (USA)

Fredrik C. Bruhn, Ångström Aerospace Corporation (Sweden)

Richard W. Cernosek, Sandia National Laboratories (USA)

Scott D. Collins, University of Maine (USA)

Xudong Fan, University of Missouri, Columbia (USA)

Ernest J. Garcia, Sandia National Laboratories (USA)

Sandeep Gulati, ViaLogy Corporation (USA)

J. Todd Hastings, University of Kentucky (USA)

Edward A. Johnson, Ion Optics Inc. (USA)

Jin-Woo Kim, University of Arkansas (USA)

Choonsup Lee, Jet Propulsion Laboratory (USA)

Sonia E. Letant, Lawrence Livermore National Laboratory (USA)

Qifa Zhou, University of Southern California (USA)

\section{Session Chairs}

1 Complex MEMS and Nanodevices

Mary J. Li, NASA Goddard Space Flight Center (USA)

Reza Ghodssi, University of Maryland, College Park (USA)

2 MEMS Adaptive Optics

Eui-Hyeok Yang, Stevens Institute of Technology (USA)

David V. Wick, Sandia National Laboratories (USA) 
3 Photonic Sensors I

Xudong Fan, University of Missouri, Columbia (USA)

Zhongyang Cheng, Auburn University (USA)

4 Photonic Sensors II

J. Todd Hastings, University of Kentucky (USA)

Gregory P. Nordin, Brigham Young University (USA)

5 Dip Pen/Nanolithography I

Debjyoti Banerjee, Texas A\&M University (USA)

James J. De Yoreo, Lawrence Livermore National Laboratory (USA)

6 Dip Pen/Nanolithography II

Paul E. Sheehan, Naval Research Laboratory (USA)

James D. Batteas, Texas A\&M University (USA)

7 MEMS/Nanosystems/Algorithms

Wolfgang Fink, California Institute of Technology (USA)

Dong-Joo Kim, Auburn University (USA)

8 Advanced MEMS Devices I

Amish Desai, Tanner Research, Inc. (USA)

C. Peter Cho, Naval Sea Systems Command (USA)

9 Advanced MEMS Devices II

Thomas G. Thundat, Oak Ridge National Laboratory (USA)

Kyung-ah Son, Jet Propulsion Laboratory (USA)

10 Nanowire Devices

Nosang V. Myung, University of California, Riverside (USA)

Cheng Luo, Louisiana Tech University (USA) 


\section{Introduction}

This conference intends to bring together scientists and engineers involved in advancing micro (MEMS) and nanotechnologies, with the focus on applications in space, defense, and homeland security. Given the enormous diversity of MEMS and nanotechnologies, we have selected several cutting-edge topics in fabrication techniques, as well as novel devices and systems, advanced algorithms, and sensor networks. The sessions are organized to facilitate the exchange of ideas and promote the discussion of recent progress in MEMS/nanotechnology research and trends toward system-level development. It is anticipated that this conference will foster cross-fertilization across many disciplines with participants being exposed to the entire range of scientific and engineering problems associated with the concepts-to-systems technology development pipeline.

MEMS and nanotechnologies are disruptive by nature, and address universal requirements for high-capability systems with small mass and size and low power consumption. Among the many issues faced by technologies making the transition from laboratory to commercial production are the demonstration of economical manufacturability and reliability during operation in the application environments. Other system-level considerations include the development of 'smart algorithms' that are required in order to realize the full potential of MEMS and nanosystems. A particular area of interest is the detection of weak signals within noisy backgrounds, arising from the fact that miniaturization, in general, degrades the sensitivity of sensors.

The ultimate benefit of MEMS and nanotechnologies lies in the creation of networks of small mass and low power sensors and actuators for numerous networked applications such as distributed sensing, aircraft/spacecraft health monitoring, biological and chemical monitoring of the environment, and for defense and security applications. Once again, in addition to developing the MEMS and nanotechnology sensing/actuation hardware for each node of the network, advanced algorithms for sensor fusion and sensor interoperability need to be developed in parallel.

The scope of the conference ranges from topics in basic research in MEMS and nanotechnology, to component and subsystem level development for space, defense, and security applications.

Papers are solicited on the following and related topics:

- innovative micro- and nanofabrication, assembly, and manufacturing technologies

- novel micro- and nanotechnology-based physical, chemical, and biological sensor devices and systems 
- micro- and nanophotonics

- micro- and nano-actuators

- systems based on micro- and nanotechnologies

- reliability considerations for micro- and nanotechnologies

- advanced algorithms for improving the performance of systems and networks based on micro- and nanotechnologies

- energy storage and generation for micro- and nanodevices and systems

- micro- and nanosensor and actuator networks.

Thomas George Zhongyang Cheng 